TURIZAM

Volume 25 , Issue 3

121-133 (2021)

ORIGINAL

SCIENTIFIC PAPER

\title{
Restoration of the Cultural Heritage Sites in Bosnia and Herzegovina as the Basis for Intercultural Dialogue and Development of Tourism
}

\author{
Adi Ćorović ${ }^{A}$, Ahmed Obralić ${ }^{A}$ \\ Received: January 2021 | Accepted: May 2021 \\ DOI: 10.5937/turizam25-30494
}

\begin{abstract}
This study deals with the buildings and sites destroyed during the war in Bosnia and Herzegovina, mostly carrying cultural and historical importance. In the last two decades in Bosnia and Herzegovina, there has been an actual reconstruction or restoration of cultural heritage, some of which have been included on the UNESCO World Heritage List. Indeed, "facsimile" reconstruction is often the case, based on the concept "as it was, where it was". Citizens of other faiths and nationalities have often given material and/or moral support to the reconstruction of "different" religious sites, confirming the thesis that they associate one part of their identity with "different". It was the first major war in Europe after World War II, where a great number of cultural goods were destroyed as symbols related to the identities of entire nations. Therefore, the response related to the reconstructions was similar to Europe's response after 1945 and represented a contribution to reconciliation, alleviation of collective trauma, and the development of intercultural dialogue and tourism. The study included an observation method for data collection. Based on conducted observations, the archival method was used for the investigation of documents and textual material, finding data in form of historical documents on architects, designers, the purpose of the settings, constructions, reconstructions, their interaction with areas, proofs on heritage values, and significance for the tourism of Bosnia and Herzegovina. All the aforementioned confirms the thesis that from today's perspective, the restored or reconstructed areas are the bearers of intercultural dialogue and the tourist potential of local communities and that reconstruction as the method has a very big role in the peace-building process.
\end{abstract}

Keywords: Intercultural dialogue, Restoration, Bosnia and Herzegovina, Tourism, Cultural heritage sites

\footnotetext{
International University of Sarajevo, Department of Engineering, Hrasnička cesta 15, 71210 Sarajevo, BiH Corresponding author: aobralic@ius.edu.ba
} 


\section{Introduction}

In the last two decades in Southeastern Europe, especially in Bosnia and Herzegovina (further in the text $\mathrm{BiH}$ ), there has been an actual reconstruction or restoration of cultural heritage, some of which have been included on the UNESCO World Heritage List. These activities were aimed at creating preconditions for intercultural dialogue and reconciliation after the 1992-95 wartime destruction. On this basis, it is possible to preserve a common cultural identity in the spirit of "unity in diversity" based on tourism and economic prosperity of the society whose foundations are shaken by the severe destruction of cultural goods related to their identity. Destruction of cultural heritage was part of the war goal: Those who destroyed them did so with the idea of destroying the identity of "others", without understanding the auto-destructive scale of the act since it was always the common cultural heritage of a traditionally multicultural society. From today's perspective, the restored or reconstructed areas are the bearers of intercultural dialogue and the tourist potential of local communities. This applies primarily to areas registered at UNESCO WHL, that is, the Old Bridge Area of the Old City of Mostar and Mehmed Paša Sokolović Bridge in Visegrad. There are also cultural heritage sites such as the Historic urban area of Sarajevo's downtown / Sarajevska čaršija (Historical core), the Church of St. Mary in Jajce, but also the Ferhadija Mosque in Banja Luka (Commission to Preserve National Monuments of B\&H, 2003) and the Orthodox Church in Mostar (Commission to Preserve National Monuments of $B \& H, 2004)$. Some of the listed areas or individual goods are by definition related to the identity of the inhabitants of all nationalities in Bosnia and Herzegovina. On the other hand, religious objects at first glance reflect the identity of only one group. This is not true in this case, taking into consideration the multicultural tradition in Bosnia and Herzegovina. Citizens of other faiths and nationalities have often given material and/or moral support to the reconstruction of "different" religious sites, confirming the thesis that they associate one part of their identity with "different". In this way, war trauma (Offenhauber et al., 2010) in Bosnia and Herzegovina caused by the destruction of Cultural Heritage Sites is healed and conditions for a successful cultural dialogue created.

Considering war events that occurred during 1992-95 in Bosnia and Herzegovina from today's perspective, it is possible to conclude that the destruction of the architectural heritage of those who are "others" and "different", was one of the main war goals. It was an attempt not only to erase someone who is "other" and "different" but also to erase the way of life that was inherited only from Bosnia and Herzegovina, where multiculturalism is considered as everlasting. It was about the systematic destruction of the architectural heritage associated with this way of existence, in another word, the phenomenon of 'urbicide', as it was defined by Martin Coward. During the war (1992-1995), 2.195 architectural cultural assets were destroyed or damaged (Corovic, 2019). Since a systematic census across the country has never been conducted, the actual numbers could probably be much higher.

"Facsimile" reconstruction is most often used in practice, based on the concept "as it was before, where it was before", which can cause criticism and perplexity in professional circuits in Europe. Nevertheless, it is necessary to understand the historical context: It was the first major war in Europe after World War II, where a great number of cultural goods were destroyed as symbols related to the identities of entire nations. Therefore, the response related to the reconstructions was similar to Europe's response after 1945 and represented a contribution to reconciliation, alleviation of collective trauma, and the development of intercultural dialogue and tourism (Corovic, 2019). 
The fact that all destructions of architectural heritage is done with predefined purpose actually indicates the importance of architectural heritage itself. Reconstruction and restoration and other methods of recovery are great tools to improve tourism, which is again a very good tool for establishing a good relationship between former conflict parties. One of the main aims of this research is to analyse the restored or reconstructed areas significant for intercultural dialogue and tourist potential of local communities.

\section{Literature review}

Studies of Legner (2018), Pavličić (2016) and many other research were conducted related to the methods of restoration, reconstruction and tourism, and about the post-war period in general in terms of cultural heritage.

In the work of Legner (2018), the subject of research was a restoration and preservation of heritage that was destroyed during the Kosovo War in the late 1990s. Many international and local organizations and funds were involved in interventions, each of them having its own aim and goals. The research results showed that reconstruction and revitalization of heritage can improve the dialogue and make a better relationship between ones who took a role in the conflict. In this research, Legner focused on Kosovar Kullas, which were supported by international actors to be restored as common and peace-building sites. As opposite to sacral buildings, Kullas was considered a secular heritage. Legner (2018) also mentioned about three kinds of interventions that can be done on heritage sites: conservation, repairs and corrections, and reconstruction. The reconstruction method is less popular but sometimes is very crucial for certain heritage sites.

In his work Pavličić (2016) mentions the link between tourism and monuments representing the Serbian population in Kosovo. Pavličić (2016) stands that tourism and touristic promotions were used as a tool of the newly formed Kosovo state to neglect the presence of the Serbian population. The author in this research focused on the passive treatment to the restoration of four heritage sites reflecting centuries of the existence of Serbs in Kosovo, sites that are listed on UNESCO WHL [Internet 1].

The war conflict and tourism correlation were the subject of research by Kasssouha (2016). Kassouha (2016) stands that reconstruction creates a new heritage created by the war itself. He stands there are two phases of tourism in a certain area, the one that was active before the war that could be a cultural tourism, bathing tourism, etc and the other one is dark or memory tourism. This paper was about two Bosnian cities, Sarajevo and Mostar. Alluri (2009) analysed the role of tourism in the peace building process in Rwanda since Rwanda was affected by the war and genocide in 1994. The tourism sector was not so developed before the war, but having some active actors such as humanitarian agents, donors, and peace and conflict experts, tourism became a very important factor for the peace building process. He states that tourism helps in building trust, cooperation and development among people who have been former conflict parties.

Researchers Becken and Carmignani (2016) analysed the impact of tourism on post-war life. They gathered data from 126 countries in the period from 1995 to 2010 . They found that tourism had a strong impact on stabilization and that tourism increased the chance of peace. They also discussed the role of tourism in development.

International Cultural Tourism Charter (1999) is about managing tourism at places of heritage significance, where six principles were formed. One of the principles was that tourism 
and conservation activities at the same time bring benefit to host communities. Also, one of the principles defines domestic and international tourism as vehicles for cultural exchange, where conservation is an important activity that provides the visitors' understanding of the community's heritage and culture. Hall (2015) after analysing the Charters (1999) on conservation and tourism, concluded that World Heritage has long been recognized as having significance for tourism. Based on research, World Heritage is seen as being geared towards Western perceptions of heritage as a powerful tool for tourism promotion and development. Tourism is also defined as a justification for methods for the conservation of heritage.

Kiryakova-Dineva and Kyurova (2020) in their work on intercultural dialogue and tourism claim that communication is one very important activity that takes place inside of a regular range of different tourism activities. They consider communication as a different tourism activity, even though this type of activity does not exist as a tourism form. Communication with different cultures and different environments improve intercultural dialogue and tourism at the same time.

The correlation between cultural heritage, intercultural dialogue and tourism has been studied by Carbone (2017) who stated that tourism is one of the human activities that contribute the inter-communities understanding by the exploitation of cultural heritage. He also mentions that UNESCO (2006) defined tourism as the main tool for intercultural dialogue and cross-cultural understanding. By analysing scholars, practitioners and other bodies, the research concluded that tourism, based on the experience of cultural heritage, leads towards intercultural dialogue.

In order to reach a sustainable level of tourism, the intercultural dialogue needs to be maintained. The intercultural dialogue is fostered by acquiring knowledge of cultural heritage.

\section{Methodology}

In order to collect data, the significant architectural monuments and buildings with the national heritage in the touristic area in Bosnia and Herzegovina were observed. The observed sites are located in very highly sensitive zones in terms of the level of conflict and population structure. The study required an observation method for data collection. The observation method is mainly used in the field of architectural psychology and observing architectural designs. Based on conducted observations, the archival method was used for the investigation of documents and textual material, finding data in form of historical documents on architects, designers, the purpose of the settings, constructions, reconstructions, their interaction with areas, proves on heritage values, and significance for the tourism of Bosnia and Herzegovina.

To present data pointing out its significance for tourism, the descriptive method was used to describe variables and characteristics of the buildings, provide the historical background, the purpose of use, evidence of its status of preserved or rehabilitated heritage, and the status based on the condition before and after war 1992-1995.

\section{Restoration of the Cultural Heritage Sites in BIH}

Because of the war, it was the city's historic centers that suffered the most. Those centers symbolized the traditional multicultural way of life in $\mathrm{BiH}$, where the common life did not manifest itself in "tolerating the different" and ceding parts of the city's territories. On the contra- 
ry, it was an act of truly living, working and individuals' praying to their own God in the same space.

In that context, special attention should be paid to the casualties of the city cores of Sarajevo and Mostar by the ravages of war, due to the fact that other cities with a similar tradition were not spared as well.

The destruction of the central Bazaar - Čaršija in Sarajevo (traditional business center) which remained in the same form as it was built at the beginning of the Ottoman period in $\mathrm{BiH}$, during the $15^{\text {th }}$ and $16^{\text {th }}$ century, is evident.

In the conditions of explicit economic underdevelopment on the territory of Bosnia, at the transition from the $15^{\text {th }}$ to the $16^{\text {th }}$ century, the activity of the waqf was the economic trigger. First, Isabeg Ishaković founded a waqf in 1462, which influenced the city formation of Sarajevo in the form in which we are familiar with today. Gazi Husrev-beg successfully continued with the same mission, in the thirties of the 16th century. Consequently, at the beginning of the $17^{\text {th }}$ century, Sarajevo was the most important economic and cultural centre of Southeast Europe (Zlatar, 1996, p. 79).

Waqf has survived to this day because it was conceived as a modern corporation based on economic and market principles. Besides, Muslim artisans and merchants did not have an advantage over others in terms of space lease agreements (ijarateyma and mukata). as stated by the Gazi Husrev-begov waqf in the brochure of GHB waqf (foundation) thus, the multi-confessional character of the Sarajevo Bazaar was indirectly improved: Muslims, Catholics, Orthodox and, later, Jews worked and lived side by side under equal conditions (Gazi Husrev-begov waqf, 2006).

Isa-beg and Gazi Husrev-beg came from medieval Bosnian aristocratic families, thus it is reasonably assumed that the phenomena of multiculturalism and tolerance were rooted in the Middle Ages, which preceded the Ottoman period in Bosnia and Herzegovina.

Not coincidentally, the systematic destruction of the architectural heritage started from the archive, the place where documentation is stored, the foundation of objective historical memory. During the first half of 1992, the Oriental Institute in Sarajevo that was designed by architect, August Butscha in 1891 was destroyed (Pirnat-Spahić, 1992). Shortly afterward, the famous Sarajevo City Hall that was built in an exemplary pseudo-Moorish style, in which the National University Library was located, was destroyed as it is stated in the decision of the Commission to Preserve National Monuments of B\&H for designation of the City hall (Vijećnica) in Sarajevo (2006). Needless to say, that these treasuries of original documents and historiographical material contained documents related to the identity of all $\mathrm{BiH}$ citizens, regardless of religion, nationality, or ethnicity, even those that belonged to those who committed these acts.

It was the eclectic pseudo-Moorish style of the Sarajevo City Hall that was an attempt to reconcile different traditions (European and Oriental) in the architectural creation of the Austro-Hungarian period at the end of the $19^{\text {th }}$ century in Bosnia and Herzegovina. Although from today's perspective it can be said that it was a "mistake in good intention" of the Austro-Hungarian administration (having in mind that the local tradition has nothing to do with Moorish architecture), it is clear that the guiding idea was the traditional multicultural community of Bosnia and Herzegovina. The physical demolition of such an object was a clear attack on the idea of multiculturalism.

The indiscriminate shelling and bombing of the entire Old City of Sarajevo, a city that Pope Francesco called "European Jerusalem" [Internet 2] during his visit on June 6, 2015, is further evidence of forces seeking to physically destroy evidence of the existence of a community based on multicultural ideas. 
During the war, the places of worship of all faiths in a narrow circle of 300 meters in the Old Town were shelled: the Gazi Husrev-beg Mosque, the Old Orthodox Church, the Jewish Temples and the Catholic Cathedral. The violence against these religious buildings, today protected at the highest state level (declared national monuments of $\mathrm{BiH}$ ), is additional proof that it was not a war against certain nations or religions, but a war against the cosmopolitan way of existence.

Besides, at the very beginning of the siege of the city in 1992, villa Mandic from the Austro-Hungarian period, which represented the Museum of the Winter Olympic Games which were held in Sarajevo in 1984, was set on fire (Decision of the Commission to Preserve National Monuments of B\&H for designation of the architectural ensemble of the group of villas dating from the Austro-Hungarian period in Petrakijina street, 2009). The original posters, works, and objects related to the organization of this great sports competition that marked the recent history of Sarajevo were kept in that building. Most of them have been preserved, due to the timely relocation by the Museum's management. Today, the exhibits from the Museum of the Winter Olympic Games in Sarajevo arein the Zetra Olympic Ice Hall.

The most important and well-known Ferhadija mosque (1579, a foreman from the school of Koca Mimar Sinan) in Banja Luka was demolished in May 1993 (The decision of the Commission to Preserve National Monuments of B\&H for designation of the site and remains of the architectural ensemble of the Ferhad paša mosque, 2003). After the war, the day of demolition of the Ferhadija mosque was proclaimed an official day of the mosques in $\mathrm{BiH}$ [Internet 3]. As reported by the portal Historija (2001), during the laying of the foundation stone of the mosque to be reconstructed, on May 7, 2001, there was a riot where one person was killed.

The City of Mostar suffered a similar fate in the period 1992-1995. Primarily, it refers to events related to the symbol of the city - the famous Old Bridge. It is a masterpiece of Ottoman architecture, built-in 1568 by the famous builder Hajrudin, which was demolished in November 1993 as stated in The decision of the Commission to Preserve National Monuments of B\&H for designation of The architectural ensemble of the Old Bridge and towers in Mostar (2004). It was about something bigger than the demolition of the stone monument itself: the symbol of the possibility of coexistence of the 'others' and the 'different' and the traditional organic connection of the two parts of the unique city through which the river Neretva passes was destroyed.

The famous Orthodox Cathedral of the Holy Trinity in Mostar suffered a similar fate as well. The construction of the Orthodox Cathedral was entrusted by the Mostarans to master craftsman Andrija Damjanov, who previously completed works on the construction of the Orthodox Cathedral in Sarajevo from 1868. The church in Mostar is larger than the one in Sarajevo, and it is interesting for its exceptional fit into the Herzegovinian architectural environment.

It features elements of Byzantine and post-Byzantine architecture, Serbian-Byzantine architecture, as well as elements of Romanesque, Gothic, Levantine Baroque and Islamic architecture, while elements of Baroque are manifested in the shapes and details of the bell tower (Kadijević, 1997, p. 23). Orthodox Cathedral in Mostar was shelled on 7-8 June 1992, and on 15th of June 1992, the bell-tower was knocked down and the church was set on fire. Shortly afterward the remains of the church were dynamited (Mileusnić, 1994, p. 80.) as stated in the aforementioned Decision.

The symbols of war destruction, urbicide, ethnic cleansing, segregation, and destruction, the destroyed architectural heritage got a chance to become the foundation and starting point of intercultural dialogue and economic development of local communities in the early postwar period. 
Already in 1996, a model of the reconstruction of the Old Bridge in Mostar was exhibited at the international festival "Triennale di Milano", at the stand of Bosnia and Herzegovina that was conceived under the motto "From minimum biological to maximum creative". The idea for the reconstruction of the destroyed symbol of the city comes along during the war, immediately after its demolition.

The reconstruction of the Old Bridge began, under the auspices of UNESCO, on 29th September 1997. The rehabilitation plan provided the reconstruction of the Old Bridge, in order to restore it to its prior condition, the complete restoration of the Herceguša, Tara and Halebija towers, the reconstruction of the Sultan Selim masjid and other buildings.

In the part of the complex on the left bank of river Neretva, the introduction of cultural facilities and cultural-religious facilities used for the Sultan Selim masjid was provided, as well as the introduction of cultural and catering facilities within the part of the complex on the right bank as referred in The decision of the Commission to Preserve National Monuments of $\mathrm{B} \& \mathrm{H}$ for designation of The architectural ensemble of the Old Bridge and towers in Mostar. Finally, the Old Bridge Area of the Old City of Mostar was registered in the WHL of UNESCO in 2005. Reconstruction of the Old Bridge and the city center of Mostar was a significant stimulus to the economic development of the entire city, especially in the field of tourism. Federal part of $\mathrm{BiH}$ is registering a positive trend of growth of tourist turnover which is visible from the following table.

Table 1. Achieved tourist arrivals and overnights of tourists in the Federation of Bosnia and Herzegovina in the period 2017-2019

\begin{tabular}{|c|c|c|c|c|c|c|}
\hline \multirow{2}{*}{} & \multicolumn{3}{|c|}{ Achieved arrivals } & \multicolumn{3}{c|}{ Achieved overnights } \\
\cline { 2 - 7 } & Total & Domestic & Foreign & Total & Domestic & Foreign \\
\hline 2017 & 948,994 & 209,830 & 739,164 & $1,860,862$ & 363,971 & $1,496,891$ \\
\hline 2018 & $1,071,097$ & 228,108 & 842,989 & $2,095,517$ & 413,282 & $1,682,235$ \\
\hline 2019 & $1,226,975$ & 255,606 & 971,369 & $2,379,701$ & 478,496 & $1,901,205$ \\
\hline $2019 / 2017$ & $+29,29 \%$ & $+21,81 \%$ & $+\mathbf{3 1 , 4 1 \%}$ & $\mathbf{+ 2 7 , 8 8 \%}$ & $\mathbf{+ 3 1 , 4 6 \%}$ & $\mathbf{+ 2 7 , 0 1 \%}$ \\
\hline
\end{tabular}

Source: Internet 4

The data in Table 1. indicate growth in both tourist arrivals and overnights in the period 2017-2019. Foreign tourists participate with the largest market share which clearly indicates that $\mathrm{BiH}$ is recognized on the international tourist market.

The tourist season in 2019 registered a tremendous success in both Mostar and County of Herzegovina-Neretva. The city of Mostar was visited by approximately a million of tourists, while the county was visited by two million tourists, according to the President of the Tourist Board of County of Herzegovina-Neretva [Internet 5].

In addition to economic profitability, it was an important moment for the relaxation of relations among the people of Mostar, given it being a universal cultural symbol, whose value is recognized by all residents regardless of religion and nation. All of these aforementioned improved relations have actively contributed to the multicultural dialogue (Dnevni list, 2018).

Such a situation caused a chain reaction of positive thoughts, events and outcomes in 2010, the reconstruction of the almost completely demolished Orthodox Cathedral of the Holy Trinity, as showed in Figure 1. and 2. in Mostar began. The restoration of the Church symbolizes much more than it seems at first glance. It is about the restoration of one of the symbols of the city on Neretva, but also represents the presence of Orthodox that lived in Mostar for centuries [Internet 6]. 
The reconstruction was planned to be completed by 2019 , on the anniversary of the establishment of the Diocese of Hum, today well-known as Zahumlje-Herzegovina and Primorje. It was established in 1219 on Pelješac by Saint Sava who appointed the first bishop.

Until the construction of the Temple of Saint Sava in Belgrade, by the end of the eighties, the Mostar Cathedral was the largest religious building in the Balkans [Internet 6].
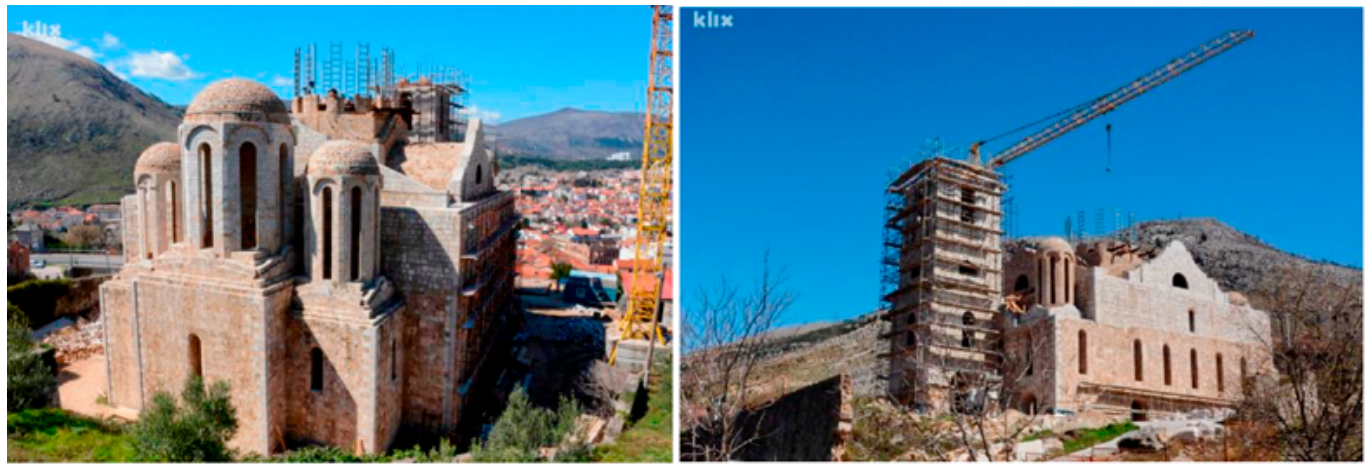

Figure 1 and 2. The Mostar Cathedral

Source: Internet 6

The Ferhadija Mosque in Banja Luka was finally reconstructed after severe incidents in 2001 according to the system "come era, dove era" on May 6, 2016 [Internet 7]. Significantly, all key representatives of the political and cultural life of Banja Luka of all nationalities attended the opening ceremony of the mosque, proving that it is a universal symbol and an opportunity to renew a multicultural dialogue roughly interrupted by the 1993 demolition and the 2001 incident.

As referred in The decision of the Commission to Preserve National Monuments of $\mathrm{BiH}$ for designation of The architectural ensemble of the group of villas dating from the Austro-Hungarian period in Petrakijina street, buildings were also renovated in Sarajevo - symbols that are located outside the main center of the Old Town: Works on the reconstruction of Villa Mandić (Figure 3), where the Olympic Museum was located as presented in Figure 3 [Internet 8], began in 2000 and continued in 2005 , as stated in the aforementioned decision.

The renovation continued in 2018, and the completion of works was planned for February 2019 during the Winter Youth Olympic Games (EYOF) held in Sarajevo (Numankadic, 2018).

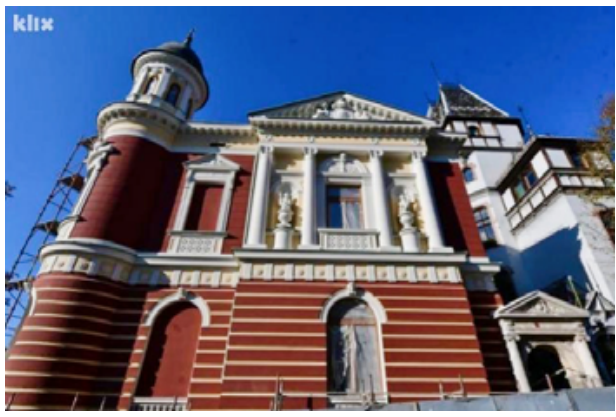

Figure3. The Olympic Museum

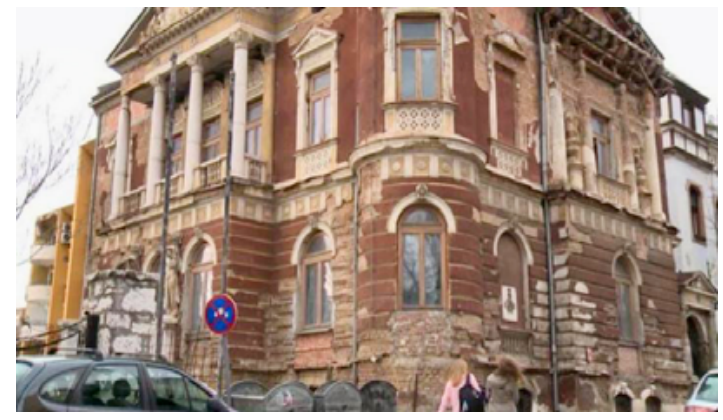

Figure 4. Villa Mandić

Source: The decision of the Commission to Preserve National Monuments of BEH for designation of The architectural ensemble of the group of villas dating from the Austro-Hungarian period in Petrakijina street (2009) 
Such developments contribute to the multicultural dialogue, considering that the territory of Sarajevo was divided according to the 1995 Peace Agreement for $\mathrm{BiH}$ into a central part of the city including the Olympic mountain Bjelasnica and the eastern part recognized as a separate unit belonging to another entity within the same state of Bosnia and Herzegovina, and it includes the second Olympic mountain Jahorina.

In February 2019, the cities of Sarajevo and East Sarajevo took over the organization of the Winter Youth Olympics (EYOF) and East Sarajevo with the participation of athletes from 46 countries as stated at the official website of the City council [Internet 9]. In that way, the parts of the same City, which were otherwise divided by administrative boundaries, were connected. The reconstruction of Villa Mandić with the associated Olympic Museum is an additional tourist attraction, but also a symbol of the idea of openness, cosmopolitanism, and harmonious dialogue of different cultures.

From the end of the siege of Sarajevo at the end of 1995 until today, many great strides have been made in the reconstruction of the Old Town and war-damaged places of worship of all faiths. Mosques, churches, and synagogues are not only places of prayers, but also open tourist attractions that attract tourists, raising awareness of the possibilities of a multi-ethnic society. At the same time, they bring economic benefits to the local community. Considering once again that the first waqfs in Sarajevo that were founded in the $15^{\text {th }}$ and $16^{\text {th }}$ century were economic institutions based on a multicultural philosophy. Thus, even today in the $21^{\text {st }}$ century, the thesis regarding the direct connection between the economy and the idea of multiculturalism is confirmed.

\section{The Post-conflict Interventions and Tourism}

Due to strategy regarding reconstructions, Sarajevo has recorded over a million tourist visits in 2018, which is the largest number of visits since the organization of the XIV Winter Olympic Games, which took place in Sarajevo in 1984 [Internet 10].

The authorities of Sarajevo Canton were surprised by this development. Due to the absence of qualified staff, they plan to open a Tourist Academy, and the Tourist Board of KS motivates young people to help develop tourism through research and innovative solutions. Thus, a competition was announced for high school students and students in the school year 2018/2019. It was a rationale form forthcoming graduation papers, seminar, graduate and master's theses, doctoral dissertations, projects and other research in the field of tourism [Internet 10].

It should not be underestimated that the previous restoration of cultural heritage in $\mathrm{BiH}$, as a basis for intercultural dialogue and development of tourism, took place mainly according to the matrix "come era, dove era", which in today's European practice, especially in Italy where it is characterized as "falso storico". In this way - "facsimile", all important destroyed architectural monuments and places of worship have been reconstructed so far such as the National Library located in the famous Sarajevo City Hall in Sarajevo, Ferhadija mosque in Banja Luka, the Old Bridge in Mostar, Aladža mosque in Foča and Orthodox Cathedral of the Holy Trinity in Mostar.

Even though such activities often provoke professional controversy and critical views, it is necessary to comprehend the historical moment when the destruction of objects-symbols brought into question entire national identities. A similar situation occurred in Europe in 1946, and in connection with that, reconstructions were carried out in Warsaw, Italy, Germany, France and other countries. 
Regardless of occasional controversies, such a practice in the post-war period proved to be justified and purposeful in terms of the development of intercultural dialogue, but also the development of profitable cultural tourism.

In the meantime, the first indications of different "critical" considerations in restoration practice such as the restoration of the historic building of the BiH Red Cross Society in Sarajevo (period 2013-2017) have developed (Corovi, Kozul, 2016), which in the long run can only have favorable consequences for the development of restoration theory and practice, as well as cultural tourism.

The intercultural dialogue is supported by the statement Pope Francis made during his visit to Sarajevo in 2015: "Guardare alle differenze come possibilità di crescita nel rispetto di tutti", he invited people to "pass from a culture of confrontation, of war, to a culture of encounter" [Internet 2]. "Sarajevo Meeting of Cultures" is the message of an inlaid marker on Ferhadija Street in the center of Sarajevo. That is a marker showing two dominant cultures shaping Sarajevo through history [Internet 11].

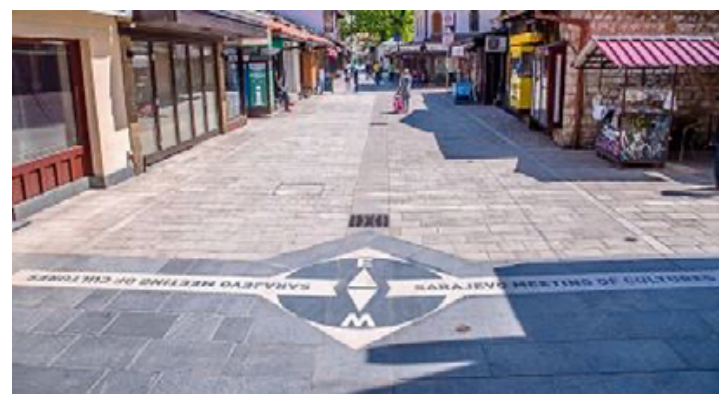

Figure 5: „Sarajevo Meeting of Cultures"

Source: Internet 12

\section{Conclusion}

The essence of life in Bosnia and Herzegovina is like in Jerusalem, where the old Muslim Nuseibeh family holds the keys to the Basilica of the Holy Sepulcher, a shrine built on the site where it is believed that Jesus Christ was buried and from where he was resurrected (Makler, 2011). In Srebrenica, Bosnia, Muslim Izet Imamović was entrusted by the Bosnian Franciscans with the keys to the only Catholic place of worship in that city [Internet 4].

Intercultural dialogue and cultural tourism consequently stimulate the development of other types of tourism: Sarajevo is experiencing an expansion of tourism related to the Olympic Mountains, and the City of Sarajevo stimulates the development of events that attract tourists, such as various festivals. In 2019, the organization of Advent [Internet 7] was held for the first time.

Intercultural dialogue and the development of cultural tourism further stimulate the protection of cultural heritage, but also the development of intangible heritage such as traditional crafts, whose products become profitable, and their sale further contributes to the development of the local community.

In order to develop the intercultural dialogue through tourism, there is a very big scope for action. European funds are good opportunity for development. One of positive examples is the participation of Sarajevo in EU funded Tourism Development and Promotion Grant 
Scheme by RCC - Regional Cooperation Council [Internet 8]. In that project, Novi Sad and Kotor were also places and parts of this project. It was very good example of intercultural dia$\log$ and presentation of mutual cultural heritage, connected through storytelling and tourism (RCC, 2019). Also the activity of different institutes of Cantons in Bosnia should be increased. Involvement of different nationalities living in Bosnia and Herzegovina together with experts from all around the world is also very important.

The development of intercultural dialogue is related to the unexpected expansion of cultural tourism in $\mathrm{BiH}$, and everything is based on the original reconstruction and restoration of damaged or endangered cultural heritage. All the aforementioned confirm the thesis that from today's perspective, the restored or reconstructed areas are the bearers of intercultural dialogue and the tourist potential of local communities.

\section{References}

Alluri, R.M. 2009. The Role of Tourism in Post-Conflict Peacebuilding in Rwanda, Swisspeace, Berne, 48.

Becken, S., Carmignani, F. 2016. Does tourism lead to peace? Annals of Tourism Research 61, 63-79.

Carbone, F. 2017. International tourism and cultural diplomacy: A new conceptual approach towards global mutual understanding and peace through tourism. Tourism: An International Interdisciplinary Journal 65(1), 61-74.

Corovic, A. 2016.Gazi Husrev-bey waqf in Sarajevo, the traditional response of economic and cultural development - Sarajevo: International forum „Bosna”, Second international scientific seminar "Sarajevo in the world”, published in the Magazine Forum Bosnae

Corovic, A. 2016. Gazi Husrev-bey waqf in Sarajevo, the traditional response of economic and cultural development” - Sarajevo: International forum „Bosna”, Second international scientific seminar "Sarajevo in the world”, published in the Magazine Forum Bosnae

Corovic, A. 2019. Restoration after the siege of Sarajevo, developments and role of the Commission to Preserve of National Monuments of Bosnia and Herzegovina (Restauri dopo l'assedio di Sarajevo, sviluppi e ruolo della Commissione per la tutela dei monumenti nazionali della Bosnia ed Erzegovina) - "Confronti. Quaderni di restauro architettonico», Arte'm, semestral magazine, a. V, n. 8-9, Naples: Arte'm, Prismi

Corovic, A., Kozulj, P. 2016. Intervention on the building of Red Cross Society of B\&H in Sarajevo, as the beginning of critical restoration approach in Bosnia and Herzegovina.Capri: Le Vie dei Mercanti. XIV International Forum: World Heritage andDegradation. Smart Design, Planning and Technologies

Corovic, A. 2019. Restoration of the Cultural Heritage Sites in Bosnia and Herzegovina as Basis for Intercultural Dialogue And Development Of Tourism, Unpublished Conference paper, $21^{\text {st }}$ General Assembly of the International Experts and Symposium Heritage as a Builder of Peace

Coward, M. 2001. Urbicide and the Question of Community in Bosnia-Herzegovina. Newcastle university library. Ph.D. - Department of Politics. Newcastle: University of Newcastle

Gazi Husrev-begov vakuf 2006. Brochure of GHB vakuf (foundation). Sarajevo: GHB vakuf.

Hall,C. 2015. World Heritage and Tourism. Tourism Recreation Research 26, 1-3, DOI: 10.1080/02508281.2001.11081170. 
ICOMOS. 1999. International Cultural Tourism Charter. Managing Tourism at Places of Heritage Signifi cance. Mexico.

Kiryakova-Dineva, T., Kyurova, V. 2020. Intercultural Dialogue: A Tool for Knowledge Sharing and a Driving Force for Tourism Development, knowledge, International Journal (38)1.

Legnér, M. 2018. Post-conflict reconstruction and the heritage process, Journal of Architectural Conservation, (24)2, 78-90, DOI: 10.1080/13556207.2018.1463663

Makler, I. 2011. Jeruzalem. Muslim Keyowner of the Basilica of the Holy Tomb (Musliman ključar bazilike Svetog groba), article in DW

Numankadic, E.2018. After the restoration of the facade the Olympic museum again looks magnificently https:/www.klix.ba/vijesti/bih/numankadic-restauracijom-fasade-olimpijski-muzej-ponovo-izgleda-velicanstveno/181124.024 (11.01.2019).

Offenhauber, D., Zimmerli, W., Albert, M.T. 2010. World Heritage and Cultural Diversity, Deutsche Nationalbibliothek, Germany

Pavličić, J. 2016. Dissonant heritage and promotion of tourism in the case of Serbian medieval monuments in Kosovo. Journal of Tourism and Cultural Change (14), 1-17. 10.1080/14766825.2016.1169349.

Spahić, N.P. 1992. Destrukcija multikulturalnog grada: Sarajevo, Informatica museologica 23, 1-4.

UNESCO. 2006. Tourism, Culture and Sustainable Development. Paris: UNESCO Publishing

Zlatar, B. 1996. The Golden Age of Sarajevo (XVI century) (Zlatno doba Sarajeva (XVI stoljeće)). Sarajevo: Svjetlost.

The decisions

The decision of the Commission to Preserve National Monuments of B\&H for designation of the City hall (Vijećnica) in Sarajevo, as national monument od B\&H, (2006).

The decision of the Commission to Preserve National Monuments of B\&H for designation of The architectural ensemble of the group of villas dating from the Austro-Hungarian period in Petrakijina street (the Mandić Villa, the Heinrich Reitter Villa, the Hermina Rädisch Villa and the Forstrath Miklau Villa) in Sarajevo as national monument od B\&H, (2009).

The decision of the Commission to Preserve National Monuments of B\&H for designation of The site and remains of the architectural ensemble of the Ferhad paša mosque - Ferhadija and graveyard in Banja Luka as national monument od B\&H, (2003).

The decision of the Commission to Preserve National Monuments of B\&H for designation of The architectural ensemble of the Old Bridge and towers in Mostar, as national monument od B\&H, (2004).

The decision of the Commission to Preserve National Monuments of B\&H for designation of The site and remains of the historic monument of the Orthodox Cathedral of the Holy Trinity in Mostar, (2004).

The decision of the Commission to Preserve National Monuments of B\&H for designation of The architectural ensemble of the Old Bridge and towers in Mostar, (2004).

\section{Internet sources}

Internet 1: http://whc.unesco.org/en/list/946 (18.09.2021)

Internet 2: https://www.repubblica.it/esteri/2015/06/06/news/il papa e arrivato a sarajevo-116181181/ (19.09.2021) 
Internet 3: http://www.historija.ba/d/98-srusena-ferhadija-dzamija/ (18.09.2021)

Internet 4: http://fzs.ba/wp-content/uploads/2020/06/4.5g.pdf (18.09.2021)

Internet 5: https://www.jabuka.tv/mostar-u-2019-godini-posjetilo-preko-milijun-turista-zelja-za-povecanjem-zracnih-linija/ (18.09.2021)

Internet 6: https://www.klix.ba/vijesti/bih/obnova-nekad-najvece-crkve-na-balkanu-nastale-iz-rivaliteta-mostarskih-i-sarajevskih-pravoslavaca/180403008 (18.09.2021)

Internet 7: http://balkans.aljazeera.net/vijesti/banja-luka-svecano-otvorena-ferhadija $(15.09 .2021)$

Internet 8: https://www.klix.ba/biznis/turisticka-zajednica-kantona-sarajevo-zabiljezila-vise-od-milion-nocenja-u2018/181117023 (18.09.2021)

Internet 9: https://sarajevo.ba/category/eyof-2019-hr/?lang=hr 11.01.2019. (18.09.2021)

Internet 10: https://www.klix.ba/biznis/u-glavnom-gradu-bih-sve-vise-turista-ove-godine-zabiljezeno-milion-nocenja/181224040 (18.09.2021)

Internet 11: https://www.rcc.int/news/521/cultural-diversity-connects-sarajevo-kotor-and-novi-sad (18.09.2021)

Internet 12: https://sarajevo.travel/en/things-to-do/sarajevo-meeting-of-cultures/4.63 $(18.09 .2021)$ 